\title{
In search of a there there
}

Sara Catherine LaHue, MD

Neurology ${ }^{\circledR}$ 2018;90:977-978. doi:10.1212/WNL.0000000000005558

A friend found Mr. Jarsdel incontinent and confused on the floor of his flower shop in San Francisco. Mr. Jarsdel was well known at our hospital due to a lengthy stay for cryptococcal meningitis earlier that year, which he developed in the setting of AIDS. His substance use disorder made continued treatment and follow-up over the subsequent months unreliable at best. I was the medicine intern in the emergency department the evening his worried friend brought him to our doors.

While performing his spinal tap, I asked Mr. Jarsdel to tell me about his favorite flowers. I wanted to distract him from my needle, but I was also curious. He could barely tell me where he was, but he proceeded to slowly describe tulips, orchids and dahlias. "Witch hazel," he added with considerable effort. "People usually forget about that one." His emaciated body made for an easy tap, and spinal fluid shot above the top of the manometer. Syrupy fluid dribbled into the vials.

Standing several feet away from his room the following morning, I began the standard presentation to my medicine attending on rounds.

"Subjectively, the patient states, 'You cured me. I'm better. I want to leave. I have business to attend to."

A few days into Mr. Jarsdel's protracted treatment the first package arrived. I thought he was just settling in to his temporary home for the coming weeks. Christmas was on the horizon, after all. No one wants to be in the hospital on Christmas.

"Mr. Jarsdel, what's in the box?" I asked during my morning visit. An open cardboard container was cast aside on his bedside table complete with shredded brown packing paper.

"I don't like the mustard here," he stated. "I wanted different mustard." He gestured to a jar of unopened whole grain Dijon mustard on a stack of magazines. "I ordered it from Amazon."

The following week, I noticed a strange illumination coming from Mr. Jarsdel's room, shining on the hallway linoleum. Strings of multicolored Christmas lights greeted me when I fully opened his door. A 2-foot Christmas tree stood in the corner by his small window.

"I like the decorations." I nodded while nervously taking stock of the situation. More open boxes spilled onto his chair with metallic ornaments peeking out of bubble wrap. "Very ... festive," I said, searching for the right word.

"I want to have a Christmas party for all the staff," he stated.

“That's so generous. But you shouldn't spend your money on us."

"But everyone has been so kind to me!" Tears suddenly cascaded down his face. "I love you all! I want to show my gratitude!"

Surprised at his outburst, I moved to comfort him. He stopped crying and his eyes narrowed.

"You don't understand." He crossed his arms. "Get out. Get out!"

\section{Correspondence}

Dr. LaHue

sara.lahue@ucsf.edu

\section{MORE ONLINE}

\section{ค Audio}

Listen to Dr. LaHue read this story

NPub.org/2kvvvu 
The trickle of packages soon became a torrent. The appearance of the mailman at the nursing station signified a pivotal change in Mr. Jarsdel's mental status. More postal workers appeared as Mr. Jarsdel graduated to Amazon Prime Now. Parcels, like blood pressure, became a vital sign discussed on our morning rounds.

"Overnight events for Mr. Jarsdel," I presented to the group. "He bought a laptop. Subjectively, he states he sold his 2 million dollar home."

The following day, I reported, "He asked for a spinal tap to 'clear my mind.' He wants to become a priest."

Later that week, I told my attending, "He said he sold his flower shop. He told me about his plan to purchase and operate different businesses 'to sell everything.' He wants to create the "next Amazon."'

Every visit to Mr. Jarsdel's room was a test of my own flexibility as his physician. He oscillated between effusive joy and despair during our conversations. While he had fungal meningitis, he was also acutely manic. I teetered on the glass wall between neurology and psychiatry as I navigated how best to care for Mr. Jarsdel-or simply try to understand what was happening to him. As a medicine intern, it was my job to integrate the recommendations I received from the many consultants. With one provider, I discussed the implications of repeat spinal fluid results; with the other, we debated diagnoses from the Diagnostic and Statistical Manual of Mental Disorders. But were these 2 diagnoses related to the same process underneath it all?

At first, I believed there was an inherent division between neurology and psychiatry. As my intern year drew to a close, I wondered how I would continue to integrate these 2 specialties as I trained to become a neurologist myself.
Connecting anatomy to function gave me great satisfaction. Predicting the location of a stroke based on a speech deficit or pattern of weakness felt like unlocking the code to human behavior. As one college mentor proudly reminded me, "Neurology is like real estate: location, location, location!" Understanding the anatomical map underlying many neurologic disorders set the stage for more targeted therapies and expectations. However, I did not know where to stick the proverbial flag on my brain atlas when confronting diagnoses such as depression, bipolar disorder, or Munchausen syndrome. In psychiatry, I was a sailor without a sextant. I could not find a there there.

It became clear to me that medicine remained influenced by 17 th century philosophy despite unmistakable 21 st century advances. Having one department centered largely on the body and the other on the mind perpetuated an unfounded dualism between mind and brain. Just as there were portraits of division heads throughout the hospital, I envisioned an oil painting of Rene Descartes joining the ranks, smiling down at me as I rushed past with my pager beeping. All the while, the care for one very sick man remained front and center. I wanted to believe that through collaboration between these fields we could find a there there amenable to intervention.

Christmas came and went for Mr. Jarsdel. Medication for his mania reduced the stream of packages but his hospital course was punctuated by wave after wave of complications. I ultimately gave up on the distinction between the illness in his brain and the one plaguing his mind.

By the time of his death, I could not tell them apart.

\section{Acknowledgment}

I would like to thank Dawn Gross, MD, PhD, Anna Hauswirth, BS, and Zoe Silverman, MA for their insightful critiques and encouragement. 


\section{Neurology}

In search of a there there

Sara Catherine LaHue

Neurology 2018;90;977-978

DOI 10.1212/WNL.0000000000005558

This information is current as of May 21, 2018

\section{Updated Information \&} Services

Subspecialty Collections

Permissions \& Licensing

\section{Reprints}

including high resolution figures, can be found at: http://n.neurology.org/content/90/21/977.full

This article, along with others on similar topics, appears in the following collection(s):

\section{Fungal infections}

http://n.neurology.org/cgi/collection/fungal_infections

HIV

http://n.neurology.org/cgi/collection/hiv

Mania

http://n.neurology.org/cgi/collection/mania

Meningitis

http://n.neurology.org/cgi/collection/meningitis

Information about reproducing this article in parts (figures,tables) or in its entirety can be found online at:

http://www.neurology.org/about/about_the_journal\#permissions

Information about ordering reprints can be found online:

http://n.neurology.org/subscribers/advertise

Neurology ${ }^{\circledR}$ is the official journal of the American Academy of Neurology. Published continuously since 1951, it is now a weekly with 48 issues per year. Copyright (O 2018 American Academy of Neurology. All rights reserved. Print ISSN: 0028-3878. Online ISSN: 1526-632X.

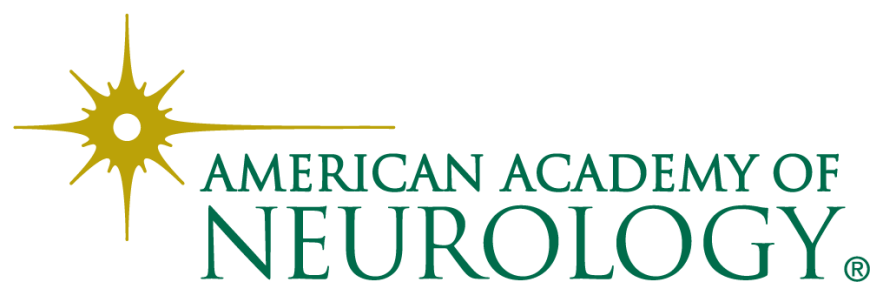

